\title{
Impact of Exchange Rate Shocks, Inward FDI and Import on Export Performance: A Cointegration Analysis
}

\author{
Van Chien NGUYEN*, Thi Tuyet DO**
}

Received: January 29, 2020 Revised: February 24, 2020 Accepted: March 1, 2020.

\begin{abstract}
The study aims to examine the effects of inward every presence of foreign investment, import, and real exchange rate shocks on export performance in Vietnam. This study employs a time-series sample dataset in the period of 2009 - 2018. All data are collected from the General Statistics Office of Ministry of Planning and Investment in Vietnam, World Development Indicator and Ministry of Finance, State Bank of Vietnam. This study employs the Augmented Dickey-Fuller test and the vector error correction model with the analysis of cointegration. The results demonstrate that a higher value of import significantly accelerates export performance in the short run, but insignificantly generates in the long run. When the volume of registered foreign investment goes up, the export performance will predominantly decrease in the both short run and long run. Historically, countries worldwide are more likely to devaluate their currencies in order to support export performance. According to the study, the exchange rate volatility has an effect on the external trade in the long run but no effect in the short run. Finally, Vietnam's export performance converges on its long-run equilibrium by roughly $6.3 \%$ with the speed adjustment via a combination of import, every presence of foreign investment, and real exchange rate fluctuations.
\end{abstract}

Keywords : Cointegration, Export Performance, Inward FDI, Real Exchange Eate Shocks, VECM

JEL Classification Code: E43, E44, F31, F62, G18

\section{Introduction}

In the trend of global economic integration, receiving international capital flows through inward FDI have been as an important engine for economic growth in each country's economy (Sultan, 2013). The expansion of the trade between the host country and the world has significantly contributed a great value to the economy. The capital inflows have entirely complemented resources as capital, technologies, modern management skills, to the developing

*First Author and Corresponding Author. Department of Banking and Finance, Faculty of Economics, Thu Dau Mot University, Binh Duong, Vietnam [Postal Address: No. 6 Tran Van On Street, Thu Dau Mot, Binh Duong, 590000, Vietnam] Tel: +84 935160577, Email: chiennv@tdmu.edu.vn or chienmpp3@gmail.com **Faculty of Human Resource Management, Trade Union University, Hanoi, Vietnam. Email: tuyetqtn|@yahoo.com_vn

(c) Copyright: The Author(s)

This is an Open Access article distributed under the terms of the Creative Commons Attribution Non-Commercial License (http://Creativecommons.org/licenses/by-nc/4.0/) which permits unrestricted noncommercial use, distribution, and reproduction in any medium, provided the original work is properly cited. countries (Tybout, 2000).

The history of Vietnam had been influenced by war lasting over 30-year-long conflict to achieve independence, but since launching of economic reform in 1986, Vietnam has rapidly transformed both politics and economic situation. Vietnam has maintained a rapid economic growth based on a socialist-oriented market economy in connection to participate a large amount of free trade agreements to generate more foreign investment and trade. Vietnamese real GDP growth rate generated by roughly $7 \%$ during 1990 to 2018. Continuously, foreign direct investment firms have been identified as an important energy of financing for a developing country. It enhances economic growth and export performance (UNCTAD, 2002; Zhang, 2005; Sultan, 2013; Nguyen, 2020). Vietnam has greatly experienced such a huge FDI inflows, export performance.

In addition, almost all countries worldwide have devalued or appreciated their currencies sharply based on the regime of exchange rate dependent on time. Throughout the long period of 1990-2018, Vietnam's shift from fixed exchange rate to a more flexible exchange rate regime. In 
recent years, State Bank of Vietnam has nearly maintained domestic currency relatively stable, with the management policy based on the overall economy balance such as import and export, public debt, balance of payments and current accounts. Because of stability of the foreign exchange rate in the local market, the volatility of exchange rate has slightly changed in comparison with the large shocks of currencies around the world. The volatility of exchange rate has been examined by Iwaisako and Nakata (2017) in the Japanese market, and Mao, Yao, and Zou (2019) in the case of China, Nouira, Plane, and Sekkat, (2011) in a sample data of 52 developing countries. In general, it is noteworthy to evaluate the effects of exchange rate shocks on export performance in Vietnam.

It is evident that export performance of a country has been predominantly influenced by a numerous of microeconomic indicators. In fact, the determinants of export performance has repeatedly stimulated academics to find a large amount of empirical analyses. Yet, finding indicators that dominated the export performance has been on among of the relevant previous papers (UNCTAD, 2002; Zhang, 2005; Sultan, 2013). In particular, the value of registered FDI inward can generate the performance of exporting based on Tybout (2000), Zhang (2005), and Sultan (2013). As presented in some recent studies, productivity spillovers may come from foreign- invested firms to domestic-invested firms in the host country (Javorcik, 2004; Wei \& Liu, 2006), by the same token, the effects of inward FDI on the volume of export can be found (Anwar \& Nguyen, 2011).

For all of the reasons discussed, the study examines the impact of exchange rate shocks, inward FDI, import on export performance. The general objectives of this study are to examine the determinants of export performance based on the macroeconomic factors in Vietnam over 1990-2018 period, as requested. Accordingly, the main aim of this study is to find the most important factors through the approach of vector error correction model (VECM). The advantage of this VECM approach is that it takes care of that econometric problems solved by stationary test, Johansen cointegration test and estimation of the linkages in the short run and long run. Thus, it helps us get more precise results. The importance of the study is to provide to the researchers, policy makers and especially the banks, Vietnamese government the determinants of the credit risk in a developing country.

The remainder of the paper is organized as follows: Section 2 presents the literature review whereas Section 3 discusses the data and data sources, methodology development and discussion of some techniques used in the study. Further, Section 4 and Section 5 indicate the results. Finally, Section 6 states the main conclusion and policy recommendations.

\section{Literature Review}

The forthcoming years have been brought such an extraordinarily good opportunity for less developing countries and countries in transition. Their economies have predominantly expanded at an unprecedented rate, changing in a large amount of reduction in poverty, diseases and crime, besides, a significant expansion of a large number of citizens to become the middle class in each country. Recently, the differential between the growth rates of developing and advanced countries expanded to more than 5 percentage points, assisted in part by the decline in the economic performance of the rich countries.

Economic growth has been focused, one of the most important ultimate goals of all economies in the world. Economic growth is closely consistent with the development of trade and viewed as a main engine to enhance the quality of human. The traditional arguments said that most less-developed countries and countries in transition have gained a large amount of FDI projects for exploitation of cheap labor or labor-intensive industries, such as food, clothing, textiles and apparel, footwear in manufacturing sector (Tybout, 2000). Further, foreign competition in the host countries has greatly made inefficient domestic producers. Inward FDI coming to the host countries has significantly diffused local firms' export activities through "indirect effect", by learning and imitating of domestic firms (UNCTAD, 2002; Zhang, 2005; Sultan, 2013).

The determinants of the export performance has been widely discussed in developing and developed countries as well as countries in transition. A large number of empirical studies have predominantly confirmed the linkages between macroeconomic factors such as exchange rate volatility, economic growth, internal trade and every presence of foreign investment (Nouira et al., 2011; Paudel \& Burke, 2015; Iwaisako \& Nakata, 2017; Mao et al., 2019). The linkages among factors have been focused on the long run and short run.

In the study on Japanese market, Iwaisako and Nakata (2017) describe that the changes in the Japanese Yen's exchange rate have frequently considered to pay attention in the policy discuss, aggregate demand in the global was significantly responsible for the changes in the exports in the country. Using a structural VAR model in relation to two exogenous shocked factors such as the shock of global demand and exchange rate. The study further discussed the effect of the structural shocks related to the changes of oil price because of widely believed that oil prices can exactly affect economic performance in each country. The study find that, exchange rate fluctuations were significantly 
associated with the changes of exports in the 1980s in Japan meanwhile the changes in global demand were more influential in the 1990s and especially in the 2000s. Further, oil price fluctuations had a somewhat large impact on Japan's exports in the 2000s.

In the study on China's economy, Mao et al. (2019) describes that the fixed exchange rate regime (FERR) can generate economic growth because of much generating productivity growth rate in tradable sector than nontradable sector. Using cross-country panel data on China from 1994 to 2007, the important role of FERR to exportled growth can be found.

As suggested in Paudel and Burke (2015), estimating the impact of the policy of exchange rate policy in Nepal on export performance during over the 1980-2010 period. Using the gravity modeling approach with the policy of long-standing currency fix against the Indian currency, it predicts that the increase of real exchange rate has unfavorably affected the exports in the country, particularly to third-party market. In addition, the competitiveness trap of exchange rate-related export has predominantly provided a reason to re-evaluate the policy of current peg on Indian rupee.

Sekkat (2016) conduct on a study in developing countries, the effect of exchange rate on export, especially export diversification in some developing countries is somewhat discussed, and the empirical finding is frequently conflicting. Sekkat (2016) also emphasized that no deep discussion of such effect can be found so far this now. It is evident that some suggestions to the impact of the undervaluation on the proportion of manufacturing sector in total exports, particularly no support can be found for the impact of misalignment on the diversification of exports within manufacturing sector.

Focused in a developed economy, Zelekha and BarEfrat (2011) conduct on a study on Israel - a developed country in the world. Israel is a high income country with GDP per capita reached 41,678.843 USD in Dec 2018, Israeli exports of goods and services to the US market include the a somewhat high value added products. Using quarterly data during the 1997-2010 period with the purpose of examining the impact of exchange rate fluctuations of exports of goods and services in Israel to the US market. Assumed by the hypothesis that the changes of exchange rate can have a negative and influential impact on export in the both short as well as long run. Developed by using of 2SLS to analyze and treat the issues of simultaneity between exchange rate and export, surprisingly, the study found that a higher level of high value added Israeli goods insignificantly appear to reduce the negative impact of fluctuations.

Nouira et al. (2011) has a study in developing countries, followed by the theoretical study that the proactive policy of exchange rate has a positive relationship with the incentives of price as undervaluation that can generate exports in each country. Using a sample dataset of 52 developing countries in the world during the years of 19912005 , it is evident that a large number of developing countries has frequently used undervaluation to boost price competitiveness of exports of goods.

More recently, and in order to capture the impact of economic growth on export performance, Ajmi, Aye, Balcilar, and Gupta (2013) has intentionally explored a study in South Africa, followed by the theory of bidirectional linkages between exports and GDP and supported by linear and non-linear test of Granger causality, using the data during 1911-2011 period in South Africa, it is evident that no evidence of significant relationship between exports and economic performance can be found. Oktora and Firdani (2019) describe that economic slowdown in the host country of exporting products can negatively affect export performance for the home country.

This paper investigates the dynamic causal link between exports and economic growth using both linear and nonlinear Granger causality tests. We use annual South African data on real exports and real gross domestic product from 1911-2011. The linear Granger causality result shows no evidence of significant causality between exports and GDP. Further, supporting this argument, the research elaborated by Hiemstra and Jones (1994) for the causality test of nonlinear Granger in New York Stock Exchange (NYSE), and it does not find a directional causality from economic performance to exports. Nonetheless, using a more powerful and less biased nonlinear test, the Diks and Panchenko (2006) test, it finds evidence of significant bi-directional causality. The study also describes that it may exist risk of misleading conclusions in connection with the Granger causality test of standard linear which neither includes of structural breaks as well as uncover nonlinearities in relationship between exports and economic performance.

Nguyen and Trinh (2019) discussed in the paper in the case of Vietnam based on the research of effect of exchange rate shocks on exports, using a time-series data from the period of 1st quarter of 2000 to 4th quarter of 2014 as well as using the method of autoregressive distributed lag (ARDL) with the bound test approach, the results describe that exchange rate shocks negatively impacts on export value in the long term. Further, a depreciation of local currency (Vietnam Dong) can impact on export value negatively in the short term, but positively in the long term, associated with J-curve effect. More strikingly, an increase in real income of a foreign economy totally reduces export value in Vietnam. 


\section{Data and Methodology}

The aim of this research is to evaluate the exchange rate, economic growth, and its impact on external trade, especially for a developing country in Southeast Asia as Vietnam. Theoretically it is believed that the findings of the research have been dependent on the quality and the diversification of the data. It highly affects the quality of analytics and research results. This section consists of descriptions of the data sources and methods used in the study. Further, the study discusses the model to be applied as well as the different methods of evaluation most suitable for the research. The different application of stationarity and cointegration is probably tested while discussing the importance of these tests for the theoretical framework for dynamic panel models will be discussed in the next part.

\subsection{Data Sources}

This study has estimated based on the secondary data in the period of $2009-2018$. All data are collected from the General Statistics Office of Ministry of Planning and Investment in Vietnam, World Development Indicator and Ministry of Finance, State Bank of Vietnam. A balanced panel data set of Vietnam during the period of 1995-2014 are used for empirical studies. The data includes exchange rate, economic growth, very presence of foreign investment and exports.

\subsection{Methodology}

Impact of exchange rate, FDI on external trade has been examined in a number of developed and developing countries, and countries in transition (see Figure 1). The results are expected to be positive for exchange rate, while effect of FDI may be either positive or negative according to theoretical consideration.

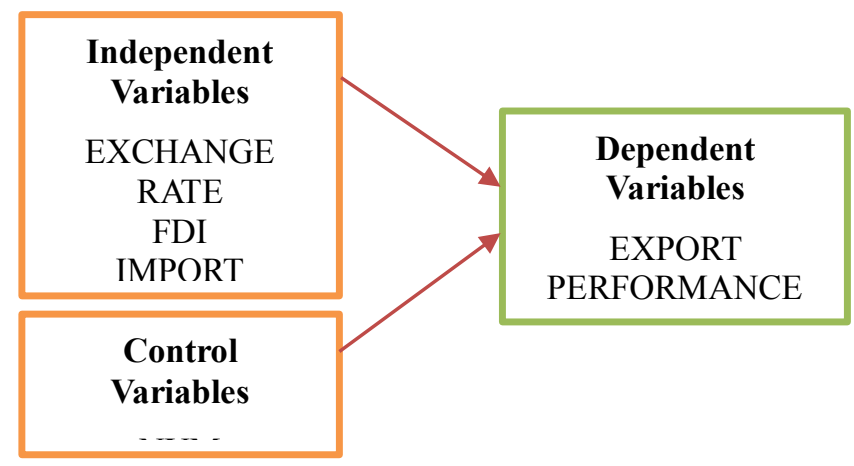

Figure 1: Research Model

Followed by the studies of Nouira et al. (2011); Paudel and Burke (2015); Iwaisako and Nakata (2017); Mao et al. (2019); Nguyen and Trinh (2019), other previous studies, the original model equation is written as follows:

$$
\mathrm{Y}=\text { function }\left(\mathrm{X}_{1}, \mathrm{X}_{2}, \mathrm{X}_{3}, \mathrm{X}_{\mathrm{i}} \ldots \mathrm{X}_{\mathrm{n}}\right)
$$

The logarithmic transformation of equation (3.1) is specifically given by:

$$
\begin{gathered}
\ln E X P=\sigma+\beta \operatorname{lnIMP}+\gamma \ln N U M+\varphi \\
\operatorname{lnREGISTER} / \text { ACTUAL }+\varepsilon \ln \text { GROWTH }+\rho \text { EXR }+u_{t}
\end{gathered}
$$

The short run and long run relationship are discussed below:

$$
\begin{aligned}
\Delta \ln E X P=\sigma+ & \sum_{i=1}^{k-1} \alpha_{i} \Delta \ln E X P_{t-i}+\sum_{j=1}^{k-1} \beta_{j} \Delta \operatorname{lnIMP} P_{t-j} \\
& +\sum_{m=1}^{k-1} \gamma_{m} \Delta \ln N U M_{t-m} \\
& +\sum_{n=1}^{k-1} \varphi_{n} \Delta \ln R E G I S T E R_{t-n} \\
& +\sum_{o=1}^{k-1} \varepsilon_{o} \Delta \ln G R O W T H_{t-o} \\
& +\sum_{p=1}^{k-1} \rho_{p} \Delta \ln E X R_{t-p}+\lambda_{p} E C T_{t-1}+u_{t}
\end{aligned}
$$

Where

$\mathrm{ECT}_{\mathrm{t}-1}=\left[\mathrm{y}_{\mathrm{t}-1}-\eta_{\mathrm{i}} \mathrm{X}_{\mathrm{t}-1}-\xi_{\mathrm{m}} \mathrm{R}_{\mathrm{t}-1}\right]$, the integrating equation and long-run model $=$ the error correction term. If ECT term is negative and significant, it means that the long run relationship exists between independent and dependent variables (Nguyen, 2020). 2018)

The subscript $t$ denotes the time period $(t=1990 \ldots$

$\mathrm{EXP}=$ the value of export at the time $\mathrm{t}$.

IMP $=$ the value of import at the time $t$. The expected sign is positive.

$\mathrm{NUM}=$ the number of foreign firms at the time $t$, is measured by the total amount of purely foreign firms, affiliate firms with foreign ownership, a proxy that is used in the studies of Hiemstra and Jones (1994), and Ajmi et al. (2013). The expected sign is also positive.

REGISTER/ACTUAL = the value of registered/actual FDI inward. The expected sign is positive. This proxy was likely to discuss based on Tybout (2000), Zhang (2005), and Sultan (2013).

GROWTH $=$ the economic growth at the time $\mathrm{t}$. The expected sign is positive. A proxy that is used in the studies of Hiemstra and Jones (1994), and Ajmi et al. (2013).

$\varepsilon=$ the error or the disturbance term

$\mathrm{EXR}=$ the real exchange rate at the time $\mathrm{t}$. The expected 
sign is positive. This proxy was likely to discuss based on Iwaisako and Nakata (2017) in the Japanese market, and Mao et al. (2019) in the case of China, and Nouira et al. (2011) in a sample dataset of 52 developing countries. EXR can be calculated by the following function:

Where

$$
E X R=N E E R * \frac{P^{f}}{P^{d}}
$$

NEER is the official nominal exchange rate. It denotes the number of domestic currency units per unit of foreign currency, measured in Vietnam Dong per dollar. Further, $\mathrm{P}^{\mathrm{f}}$ denotes foreign prices, and $\mathrm{P}^{\mathrm{d}}$ denotes the domestic prices, respectively.

\section{Results}

In the section, the study will immediately discuss results of the estimated model in the case of Vietnam. Firstly, it is to estimate the unit root test to determine the stationarity of all variables. Secondly, it is to implement the Johansen cointegration test to check for cointegration between variables. Finally, all relationships are focused, we can estimate a Vector error correction model. Finally, the study will deeply discuss the estimated model results and analyze the best model based on checking by diagnostic tests.

\subsection{Descriptive Statistics}

Table 1 describes the descriptive statistics of the variables used in this study regarding their mean, standard deviation, minimum, and maximum values. This analysis is based on time-series data. In the theory, a time-series data is known as the repeated observations on the same individuals ordered in time, it is specific to find that two sources of variance within the sample can be existed. More specifically, each individual at the time $\mathrm{i}$ is systematically different from other individuals at the time $\mathrm{j}$ in terms of variations between individual.

The results presented in Table 1 describe that, external and internal trade in Vietnam have been expanded by a large amount value over time. Vietnam has higher degrees of trade openness in recent years. In addition to FDI inflows, the every presence of foreign investment has steadily increased in the both disbursement and registered values. Further, economic growth on average in Vietnam has been maintained a high rate of 7 percent during the period of $1990-2018$. The economic growth experienced the highest level of growth rate of 9.5 percent and the lowest of 4.8 percent.
Table 1: Descriptive Statistics

\begin{tabular}{|c|c|c|c|c|c|}
\hline Variable & Obs & Mean & Std. Dev. & Min & Max \\
\hline EXP & 29 & 60.470 & 70.507 & 2.087 & 243.69 \\
\hline IMP & 29 & 63.853 & 69.262 & 2.338 & 237.18 \\
\hline NUM & 29 & 285.78 & 320.93 & 1.171 & 987 \\
\hline REGISTER & 29 & 14.312 & 15.338 & 1.284 & 71.726 \\
\hline ACTUAL & 29 & 6.589 & 5.693 & 0 & 19.1 \\
\hline GROWTH & 29 & 0.070 & 0.013 & 0.048 & 0.095 \\
\hline
\end{tabular}

Table 2 shows the correlation matrix among variables used in the study. Correlation discusses the strength and sign of linear link between two variables. In discussion to Gujarati (2004) who said that multi-collinearity existence can be found if correlation coefficient is 0.8 and more, severe multi-collinearity can be exactly present because absolute value of pairwise correlations between variables may be relatively high. Apart from actual foreign investment (ACTUAL) can badly affect the quality of the model, correlation test results emphasize that there is less multi-collinearity problem in all cases, the correlation coefficient does not exceed 0.8 so that the multi-collinearity is not present. Additionally, correlation test instantly discusses short run insights into linear link between variables, for the long run equilibrium link, we need to further discuss empirical tests in the next analysis.

Table 2: Correlation Matrix

\begin{tabular}{|c|c|c|c|c|c|c|c|}
\hline Ind. & EXP & IMP & NUM & REG & ACT & GRO & EXR \\
\hline EXP & 1 & & & & & & \\
\hline IMP & 0.99 & 1 & & & & & \\
\hline NUM & 0.54 & 0.55 & 1 & & & & \\
\hline REG & 0.64 & 0.68 & 0.53 & 1 & & & \\
\hline ACT & 0.95 & 0.97 & 0.62 & 0.78 & 1 & & \\
\hline GRO & 0.31 & 0.30 & 0.44 & 0.19 & 0.30 & 1 & \\
\hline EXR & 0.88 & 0.90 & 0.37 & 0.59 & 0.89 & 0.33 & 1 \\
\hline
\end{tabular}

Note: REG, ACT, GRO are the abbreviation for REGISTER, ACTUAL and GROWTH

\subsection{Stationary Test Results}

Table 3 shows that the result obtained from ADF test indicates that series are non-stationary. For the first difference, the values of test statistic are entirely greater than the critical values at $1 \%, 5 \%$ and $10 \%$ levels of significance, respectively. It is therefore important that the null hypothesis could not be rejected and the conclusion is that stationary of series can be found at all the levels of significance.

Based on the ADF test, we have: 
- The Null hypothesis H0: The time series is non stationary.

- The Alternative hypothesis Ha: The time series is stationary.

Performing the augmented Dickey-Fuller test, at 5\% or $10 \%$ critical value, the test statistic is less than the critical value, the null hypothesis could be rejected in favor of the alternative hypothesis.

Table 3: Augmented Dickey-Fuller (ADF) Test

\begin{tabular}{|c|c|c|}
\hline Variable & Variable & $\begin{array}{c}\text { One lag of differenced variable } \\
\text { (LD) }\end{array}$ \\
\hline $\operatorname{lnEXP}$ & -1.718 & $-2.834^{* *}$ \\
\hline $\operatorname{lnIMP}$ & -1.183 & $-4.019^{*}$ \\
\hline $\operatorname{lnNUM}$ & -1.088 & $-2.834^{* *}$ \\
\hline $\operatorname{lnREGISTER~}$ & -0.848 & $-2.832^{* *}$ \\
\hline GROWTH & -2.665 & $-2.737^{* *}$ \\
\hline $\operatorname{lnEXR}$ & -1.723 & $-2.746^{* *}$ \\
\hline
\end{tabular}

\subsection{Johansen Cointegration Tests}

Table 4 shows that an existence of a lag difference can be found at 5 percent level of significance. Further, the long run relationship between $\operatorname{lnEXP}$ and other variables will correctly analyze through VECM estimation method.

Based on the Johansen test, we have:

- The Null hypothesis H0: There is no cointegration.

- The Alternative hypothesis Ha: There is cointegration.

It is evident that Johansen test has been the best way to test for the characteristics of cointegration in a multivariate equation, is calculated by between pairs of indicators. According to the theory of Johansen test, the trace statistic is less than the critical value, the null hypothesis of no cointegration is exactly rejected in favor of the alternative hypothesis at the suitable level of significance.

Table 4: Johansen Test

\begin{tabular}{|c|c|c|c|c|c|}
\hline Rank & \multicolumn{2}{|c|}{ Hypothesized } & $\begin{array}{c}\text { Eigenv } \\
\text { alue }\end{array}$ & $\begin{array}{c}\text { Trace } \\
\text { Statistic }\end{array}$ & $\begin{array}{c}\mathbf{5 \%} \text { critical } \\
\text { value }\end{array}$ \\
\hline & H0 & Ha & & & \\
\hline 0 & $\mathrm{r}=0$ & $\mathrm{r}>=1$ &. & 52.3094 & 33.46 \\
\hline 1 & $\mathrm{r}<=1$ & $\mathrm{r}>=2$ & 0.855 & $23.2647^{*}$ & 27.07 \\
\hline 2 & $\mathrm{r}<=2$ & $\mathrm{r}>=3$ & 0.577 & 13.6454 & 20.97 \\
\hline 3 & $\mathrm{r}<=3$ & $\mathrm{r}>=4$ & 0.396 & 11.3988 & 14.07 \\
\hline 4 & $\mathrm{r}<=4$ & $\mathrm{r}>=5$ & 0.344 & 1.9140 & 3.76 \\
\hline 5 & $\mathrm{r}<=5$ & $\mathrm{r}>=6$ & 0.068 & & \\
\hline
\end{tabular}

\subsection{Estimation of VECM with (p) lags}

Table 5 and Table 6 show the long run relationship and short run relationship, respectively. To estimate the VECM approach, our results show the short run and long run relationship between external trade and other indicators.

$\mathrm{ECT}_{\mathrm{t}-1}=\left[\mathrm{y}_{\mathrm{t}-1}-\eta_{\mathrm{j}} \mathrm{X}_{\mathrm{t}-1}-\xi_{\mathrm{m}} \mathrm{R}_{\mathrm{t}-1}\right]$, the integrating equation and long-run model

We have two cases. First, the model has two independent variables (lnNUM and lnGROWTH). Second, the model does not have these independent variables.

$$
\mathrm{ECT}_{\mathrm{t}-1}=1.00 \operatorname{lnEXP} \mathrm{t}_{\mathrm{t}-1}+0.06 \ln \operatorname{IMP}_{\mathrm{t}-1}-0.02 \operatorname{lnNUM} \mathrm{T}_{\mathrm{t}-1}-
$$
$0.36 \operatorname{lnREGISTER}$ t-1 $_{-1}-0.26 \operatorname{lnGROWTH}_{\mathrm{t}-1}-4.78 \ln \operatorname{EXR}_{\mathrm{t}-1}-$ 42.84

$$
\begin{aligned}
\Delta \ln E X P=\sigma+ & \sum_{i=1}^{k-1} \alpha_{i} \Delta \ln E X P_{t-i}+\sum_{j=1}^{k-1} \beta_{j} \Delta \operatorname{lnIMP} P_{t-j} \\
& +\sum_{m=1}^{k-1} \gamma_{m} \Delta \ln N U M_{t-m} \\
& +\sum_{n=1}^{k-1} \varphi_{n} \Delta \ln R E G I S T E R_{t-n} \\
& +\sum_{o=1}^{k-1} \varepsilon_{o} \Delta \ln G R O W T H_{t-o} \\
& +\sum_{p=1}^{k-1} \rho_{p} \Delta \ln E X R_{t-p}+\lambda_{p} E C T_{t-1}+u_{t}
\end{aligned}
$$

$$
\begin{aligned}
\Delta \ln E X P=0.130 & -0.187 \Delta \ln E X P_{t-1}+0.503 \Delta \ln I M P_{t-1} \\
& -0.018 \Delta \ln N U M_{t-1} \\
& -0.147 \Delta \ln R E G I S T E R_{t-1} \\
& -0.032 \Delta \ln G R O W T H_{t-1} \\
& +0.166 \Delta \ln E X R_{t-1}-0.259 E C T_{t-1}+u_{t}
\end{aligned}
$$

Regarding ECT coefficient, the adjustment term is minus 0.259 and is statistically significant at the $10 \%$ level. Theoretically, Johansen cointegration test ECT(-1) measures the speed of adjustment of the short run to the long run. It is expected to be between -1 and 0 . It suggests that the export performance converges on its long-run equilibrium by at least $6.30 \%$ with the speed adjustment via the channel of import, foreign investment, and real exchange rate fluctuations. Another explanation of the coefficient of the speed of adjustment implies that $6.30 \%$ of the disturbance in the short run will be corrected each year.

$$
\begin{aligned}
& \mathrm{ECT}_{\mathrm{t}-1}=1.000 \ln \mathrm{EXP}_{\mathrm{t}-1}+0.494 \operatorname{lnIMP} \mathrm{P}_{\mathrm{t}-1}- \\
& 0.406 \ln R E G I S T E R_{t-1}-6.429 \ln \operatorname{EXR}_{\mathrm{t}-1}-57.350 \\
& \begin{aligned}
\Delta \ln E X P=0.088 & -0.253 \Delta \ln E X P_{t-1}+0.600 \Delta \operatorname{lnIMP} P_{t-1} \\
& -0.120 \Delta \ln R E G I S T E R_{t-1} \\
& +0.206 \Delta \ln E X R_{t-1}-0.063 E C T_{t-1}+u_{t}
\end{aligned}
\end{aligned}
$$


Table 5: Results of Vector Error Correction Model

\begin{tabular}{|c|c|c|c|c|}
\hline \multicolumn{5}{|c|}{ Dependent Variables: $\triangle \operatorname{InEXP}$} \\
\hline Variables & Coef. & Coef. & Coef. & Coef. \\
\hline $\begin{array}{c}\text { Error } \\
\text { Correction }\end{array}$ & $\begin{array}{c}-0.2593 \\
(0.040)^{*}\end{array}$ & $\begin{array}{c}-0.063 \\
(0.351)\end{array}$ & $\begin{array}{l}-0.0281 \\
(0.838)\end{array}$ & $\begin{array}{c}-0.192 \\
(0.380)\end{array}$ \\
\hline$\Delta \operatorname{lnEXP} P_{t-1}$ & $\begin{array}{l}-0.1868 \\
(0.409)\end{array}$ & $\begin{array}{c}-0.253 \\
(0.271)\end{array}$ & $\begin{array}{l}-0.3557 \\
(0.272)\end{array}$ & $\begin{array}{l}-0.3105 \\
(0.310)\end{array}$ \\
\hline$\Delta \operatorname{lnIMP} \mathrm{t}_{\mathrm{t}-1}$ & $\begin{array}{c}0.5027 \\
(0.018)^{*}\end{array}$ & $\begin{array}{c}0.6002 \\
(0.004)^{* *}\end{array}$ & $\begin{array}{l}0.4276 \\
(0.158)\end{array}$ & $\begin{array}{l}0.3243 \\
(0.279)\end{array}$ \\
\hline$\Delta \ln \mathrm{NUM}_{\mathrm{t}-1}$ & $\begin{array}{l}-0.0185 \\
(0.203)\end{array}$ & & $\begin{array}{l}-0.0023 \\
(0.895)\end{array}$ & \\
\hline$\Delta \operatorname{lnREGISTER} \mathrm{t}_{\mathrm{t}-1}$ & $\begin{array}{c}-0.1465 \\
(0.002)^{* *}\end{array}$ & $\begin{array}{c}-0.120 \\
(0.011)^{*}\end{array}$ & & \\
\hline$\Delta \ln A C T U A L_{t-1}$ & & & $\begin{array}{l}0.0248 \\
(0.861)\end{array}$ & $\begin{array}{l}0.0226 \\
(0.836)\end{array}$ \\
\hline$\Delta \operatorname{lnGROWTH} H_{\mathrm{t}-1}$ & $\begin{array}{l}-0.0327 \\
(0.762)\end{array}$ & & $\begin{array}{l}-0.0039 \\
(0.983)\end{array}$ & \\
\hline$\Delta \operatorname{lnEXR} R_{t-1}$ & $\begin{array}{l}0.1663 \\
(0.516)\end{array}$ & $\begin{array}{l}0.2063 \\
(0.424)\end{array}$ & $\begin{array}{l}0.6060 \\
(0.397)\end{array}$ & $\begin{array}{l}0.4687 \\
(0.471)\end{array}$ \\
\hline $\mathrm{C}$ & $\begin{array}{c}0.1299 \\
(0.002)^{* *}\end{array}$ & $\begin{array}{l}0.0887 \\
(0.113)\end{array}$ & $\begin{array}{c}0.1496 \\
(0.015)^{*}\end{array}$ & $\begin{array}{c}0.1731 \\
(0.002)^{* *}\end{array}$ \\
\hline
\end{tabular}

Note: $(* *),(*)$ denote significance at $1 \%$ and $5 \%$, respectively.

Table 6: Johansen Normalization Restriction Imposed

\begin{tabular}{|c|c|c|c|c|c|c|}
\hline Beta & Coef. & $\begin{array}{c}\text { Std. } \\
\text { Er. }\end{array}$ & $\mathbf{Z}$ & $\mathbf{P}>[\mathbf{z}\rceil$ & \multicolumn{2}{|c|}{$\begin{array}{c}\mathbf{9 5 \%} \text { Conf. } \\
\text { Interval }\end{array}$} \\
\hline $\operatorname{lnEXP}$ & 1.00 & & & & & \\
\hline $\operatorname{lnIMP}$ & 0.06 & 0.04 & 1.32 & 0.18 & -0.02 & $\begin{array}{c}0.15 \\
1\end{array}$ \\
\hline $\operatorname{lnNUM}$ & -0.02 & 0.00 & -3.80 & 0.00 & -0.04 & -0.01 \\
\hline $\begin{array}{c}\text { lnREGISTE } \\
\text { R }\end{array}$ & -0.36 & 0.03 & -10.3 & 0.00 & -0.43 & -0.29 \\
\hline $\ln$ GROWTH & -0.26 & 0.06 & -3.85 & 0.00 & -0.39 & -0.12 \\
\hline $\operatorname{lnEXR}$ & -4.78 & 0.19 & -25.0 & 0.00 & -5.15 & -4.40 \\
\hline $\mathrm{C}$ & 42.84 & & & & & \\
\hline
\end{tabular}

\subsection{Check in Diagnostic Tests}

Table 7 indicates that we cannot reject the null hypothesis that there is no autocorrelation in the residuals at the first lag order. It is evident that there is no hint of model misspecification. Further, Jarque - Bera test at Table 8 has been employed for normality test, we found that the dirturbances of model will be normally distributed. Regarding the equation, InNUM and lnGROWTH should drop out of the model because these variables significantly decrease the quality of the model with less normally distributed of errors that can generate more biased estimators. In addition to stability test, our results at Figure 2 show that eigenvalues are strictly less one, thus showing the stability of the bivariate model.
Table 7: Lagrange Multiplier Test (Autocorrelation Test)

\begin{tabular}{|c|c|c|c|}
\hline Lag & Chi2 & df & Prob>chi2 \\
\hline 1 & 10.8704 & 16 & 0.8714 \\
\hline
\end{tabular}

Note: H0: no autocorrelation at lag order

Table 8: Jarque-Bera test

\begin{tabular}{|c|c|c|c|}
\hline Equation & Chi2 & df & Prob $>$ chi2 \\
\hline D_lnEXP & 1.327 & 2 & 0.51517 \\
\hline D_lnNUM & 105.359 & 2 & 0.00000 \\
\hline D_lnREGISTER & 2.129 & 2 & 0.34488 \\
\hline D_lnGROWTH & 15.239 & 2 & 0.00049 \\
\hline D_lnEXR & 0.012 & 2 & 0.99389 \\
\hline
\end{tabular}

\section{Discussion}

Regarding the estimation results with the approach of VECM, our results show the short run and long run relationship between external trade and other indicators in the period 1990-2018 in Vietnam, as follows:

The short run linkages shown in Table 5, coefficients of the first lag of import and FDI are statistically significant at the 1 percent level but positive for IMP and negative for FDI. It predicts that if import value increases, external trade will be probably generated in the short run. This finding is likely to be consistent with the studies of Nguyen and Trinh (2019) conducted in Vietnam. Further, if the value of registered FDI in Vietnam goes up by one percent this year, the external trade will be entirely decreased by $0.12 \%$ percent in next year.

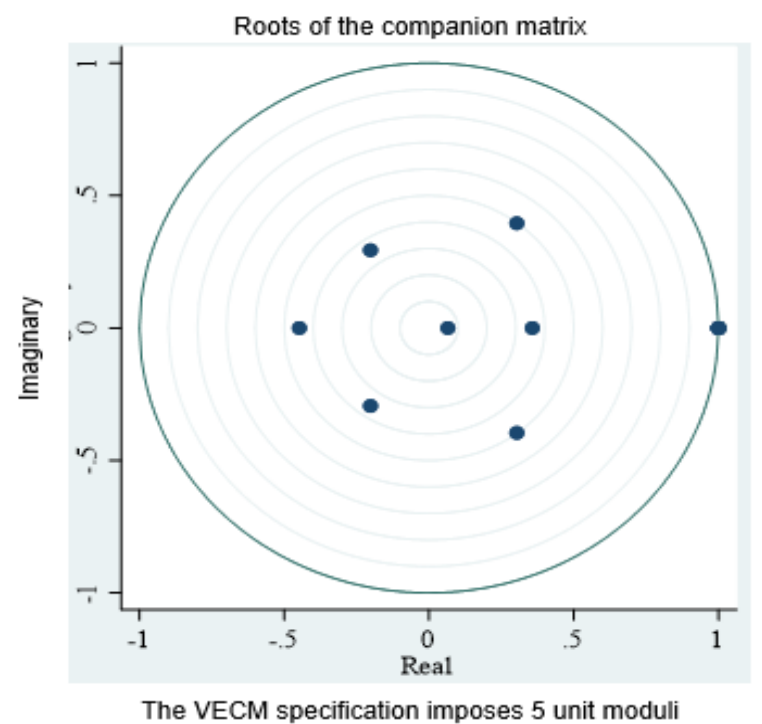

Figure 2: Stability Test 
The long run linkages shown in Table 6 with the error correction (ECT) will be explained. Followed by the results, it predicts that an increase in import value is insignificantly correlated with a change in export value. It means that a greater volume of import to Vietnam can insignificantly affect export performance. In addition to FDI, a higher level of FDI registered volume can positively increase in external trade. It predicts that a $1 \%$ increase in registered FDI inward is associated with a $0.4 \%$ increase in external trade. This evidence is supported the fact of FDI inward since economic reforms initiated in Vietnam in 1986, Vietnam has been a higher degree of trade openness, especially in recent years and still a developing country. Vietnam needs to import the products from the advanced economies as machinery, equipment. Further, some imported products have been become the intermediate goods for manufacturing process in the country. In fact, during the first stages of development process, Vietnam has to accept an export substitution economy based on an export substitution industrialization.

In terms of exchange rate, the exchange rate volatility has an effect on the external trade in the long run. Theoretically, a weaker level of the domestic currency can totally stimulate exports (and make import more expensive as well). In the case of Vietnam, the existence of a policy of a weaker local currency over time has significantly generated export. This evidence is not supported by Kemal and Qadir (2005) who said that exchange rate is negatively consistent with export activities. This result is in line with the studies of Nguyen and Trinh (2019), a depreciation of local currency impacts export negatively in the short run but positively in the long run.

\section{Conclusions}

The paper aims to estimate the impact of exchange rate shocks, inward FDI and import on export performance - a cointegration analysis of Vietnam during the period from 1990 to 2018. The objective of the paper was to investigate how exchange rate volatility, foreign investment, import, and its impact on export from a developing country in the Pacific Asia as Vietnam. All indicators are examined to check the cointegrated effects in the long-run and short-run. Further, this paper used time-series data via VECM approach to analyze stationarity test, cointegration test, stability test.

Theoretically, a depreciation in the domestic currency will predominantly increase exports and decrease imports and then increase trade balance as the $\mathrm{J}$ curve effects. Currency depreciation can take part in because of economic factors such as inflation differentials, interest rate differentials, political shocks, and credit ratings between the countries. In addition, inward FDI generates exports by investing capital in the host countries in the process of exploitation of low-cost labor, technology transfer and knowledge imitation, especially in the 2000s in Vietnam, when the country has negotiated a large number of free trade agreements with the advanced economies. Through the findings, it is evident that there exists a cointegration linkages of exchange rate, inflows of every presence of foreign investment, internal trade, and external trade.

The results of this paper demonstrate that export efficiency will be affected by exchange rate in the long run. Further, a larger volume of import to Vietnam can negatively affect a value of export. In addition to FDI, a higher level of registered FDI volume can positively increase in external trade. It predicts that a $1 \%$ increase in registered inward FDI is associated with a $0.4 \%$ increase in external trade in the long run but a negative impact can be found in the short run. In addition to import effect, it predicts that if import value is to increase, export volume will negatively generate in the short run.

The findings have led some major recommendations. Firstly, Vietnam government continues to relieve the procedures of doing business, especially for the inward FDI in order to welcome more this capital to the country. More FDI projects help to promote more exports by facilitating tariff barriers to new and larger markets. It helps economic growth and job creation in the host country. Secondly, The State Bank of Vietnam (SBV) continues to manage the flexible exchange-rate system based on the linkages of supply and demand, it is really important that a currency depreciation causes export goods and services cheaper, besides, import goods dearer. Further, Vietnam needs to play some efforts to develop capital markets in order to interact and integrate the global market as some developed countries have conducted (Wong \& Bhatti, 2019), it will enhance more export performance in the country.

\section{References}

Anwar, S., \& Nguyen, P. L. (2011). Foreign direct investment and trade: The case of Vietnam. Research in International Business and Finance, 25(1), 39-52.

Ajmi, A. N., Aye, G. C., Balcilar, M., \& Gupta, R. (2013). Causality between exports and economic growth in South Africa: Evidence from linear and nonlinear tests (Working Papers 201339). University of Pretoria, Department of Economics.

Diks, C., \& Panchenko, V. (2006). A new statistic and practical guidelines for nonparametric Granger causality testing. Journal of Economic Dynamics and Control, 30(9-10), 16471669.

Hiemstra, C., \& Jones, J. D. (1994). Testing for linear and nonlinear Granger causality in the stock price-volume relation. 
Journal of Finance, 49(5), 1639-1664.

Iwaisako, T., \& Nakata, H. (2017). Impact of exchange rate shocks on Japanese exports: Quantitative assessment using a structural VAR model. Journal of the Japanese and International Economies, 46(C), 1-16.

Javorcik, B. S. (2004). Does foreign direct investment increase the productivity of domestic firms? In search of spillovers through backward linkages. The American Economic Review, 94(3), 605-627.

Kemal, M. A., \& Qadir, U. (2005). Real exchange rate, exports, and imports movements: A trivariate analysis. The Pakistan Development Review, 44(2), 177-195.

Mao, R., Yao, Y., \& Zou, J. (2019). Productivity growth, fixed exchange rates, and export-led growth. China Economic Review, $56(\mathrm{C})$,

$1-11$. https://doi.org/10.1016/j.chieco.2019.101311

Nguyen, T. T. V., \& Trinh, T. T. D (2019). The impact of exchange rate volatility on exports in Vietnam: A bounds testing approach. Journal of Risk and Financial Management, 12(6), $1-14$.

Nguyen, V. (2020). Human capital, capital structure choice and firm profitability in developing countries: An empirical study in Vietnam. Accounting, 6(2), pp 127-136. doi: $10.5267 /$ j.ac.2019.11.003

Nguyen, V. C. (2020). Energy consumption, income, trading openness, and environmental pollution: Testing environmental Kuznets curve hypothesis. Journal of Southwest Jiaotong University, 55(1), pp 1-10. https://doi.org/10.35741/issn.02582724.55.1.6

Nouira, R., Plane, P., \& Sekkat, K. (2011). Exchange rate undervaluation and manufactured exports: A deliberate strategy? Journal of Comparative Economics, 39(4), 584-601. DOI: 10.1016/j.jce.2011.08.002

Oktora, S. I., \& Firdani, A. M. (2019). Natural Rubber Economics between China and Southeast Asia: The Impact of China's
Economic Slowdown. Journal of Asian Finance, Economics and Business, 6(2), 55-62. https://doi.org/10.13106/jafeb.2019.vol6.no2.55

Paudel, R. C., \& Burke, P. J. (2015). Exchange rate policy and export performance in a landlocked developing country: The case of Nepal. Journal of Asian Economics, 38(6), 55-63.

Sekkat, K. (2016). Exchange rate misalignment and export diversification in developing countries. The Quarterly Review of Economics and Finance, 59(2), 1-14.

Sultan, Z. A. (2013). A causal relationship between FDI inflows and export: The case of India. Journal of Economic and Sustainable Development, 4(2). Retrieve from http://iiste.org/Journals/index.php/JEDS/article/view/4118

Tybout, J. R. (2000). Manufacturing firms in developing countries: How well do they do, and why? Journal of Economic Literature, 38(1), 11-44. DOI: 10.1257/jel.38.1.11.

UNCTAD (2002). World investment report 2002 - transnational corporations and export competitiveness. Retrieved from http://unctad.org/en/docs/wir2002_en.pdf

Wei, Y., \& Liu, X. (2006). Productivity spillovers from R\&D, exports and FDI in China's manufacturing sector. Journal of International Business Studies, 37, 544-557.

Wong, M. C. S., \& Bhatti, W. I. (2019). Developing International Sukuk in East Asia: Implications from Hong Kong Sukuk. Journal of Asian Finance, Economics and Business, 6(4), 9-17. https://doi.org/10.13106/jafeb.2019.vol6.no4.9

Zelekha, Y., \& Bar-Efrat, O. (2011). The link between exchange rate uncertainty and Israeli exports to the US: 2SLS and cointegration approaches. Research in Economics, 65(2), 100109.

Zhang, K. H. (2005). How does FDI affect a host country's export performance? The case of China. Retrieved January 10, 2020, from www.faculty.washington.edu/kariyu/cofer/xian05/paper/zhang. pdf 